\title{
Mitterrand's monetary policy A failure in the economics policy from 1981 to 1982
}

\author{
Ruoya Wang \\ Undergraduate economic student. Xiamen University, XMU, Xiamen, China
}

\begin{abstract}
This document is an introduction about the economics policies under Mitterrand's early leadership between 1981-1982. The series of economics policies made during this period was widely considered as a total failure and the author will focus on the monetary policy to introduce the policy itself and effect of this policy. In the end of this article, the author will give some evaluation about the 1981-1982 policy and some people's different opinion about Mitterrand's early policy in economy.
\end{abstract}

\section{INTRODUCTION}

The policy that the author want to discuss about between 1981-1982 was an early attempt of the whole series of policies during 1981-1995 under Mitterrand's leadership in France. This early attempt at a demand-led expansion was totally failed.

Mitterrand was the first president of The Socialist party in France who came into power in 1981 at a time when all the European countries were going through serious financial crisis since 1970s. He promised rapid growth and a reduction in unemployment.

However, as we can see in the next part of this article, Mitterrand did not keep his promise in this 1981-1982 policies [7]. The first of Mitterrand's leading periods led to considerable disillusion [7]. Following electoral promises of fast growth, reducing unemployment and redistributing income, the period leading to the second devaluation after Mitterrand's election merely showed signs of spiraling inflation, poor growth and increasing unemployment.

\section{BACKGROUND BEFORE MITTERRAND'S LEADERSHIP}

\subsection{Low increase in GDP}

First, we can see in the graph that since 1970s the growth of GDP was very low. There was even a decrease in 1980 which means the French economy was really bad at that time. This long time bad economic situation can be a hard problem for Mitterrand to solve, which means it is difficult for Mitterrand to be succeed.

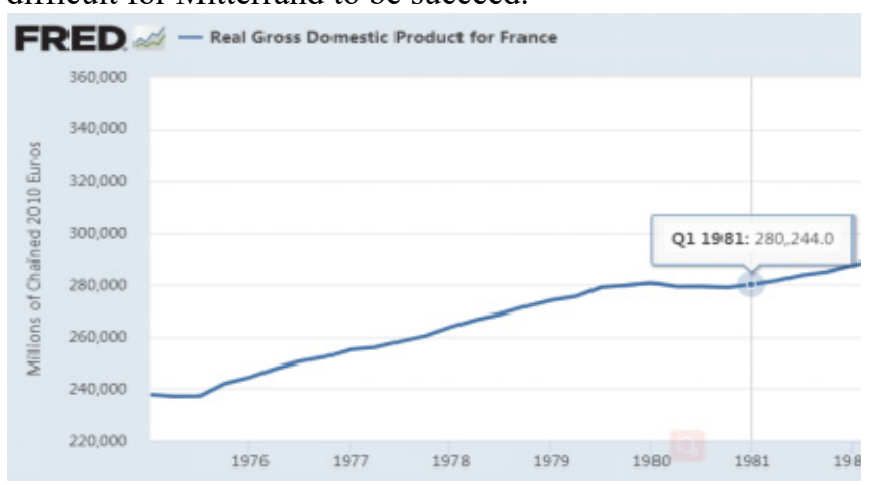

Figure 1. Real Gross Domestic Product for France.

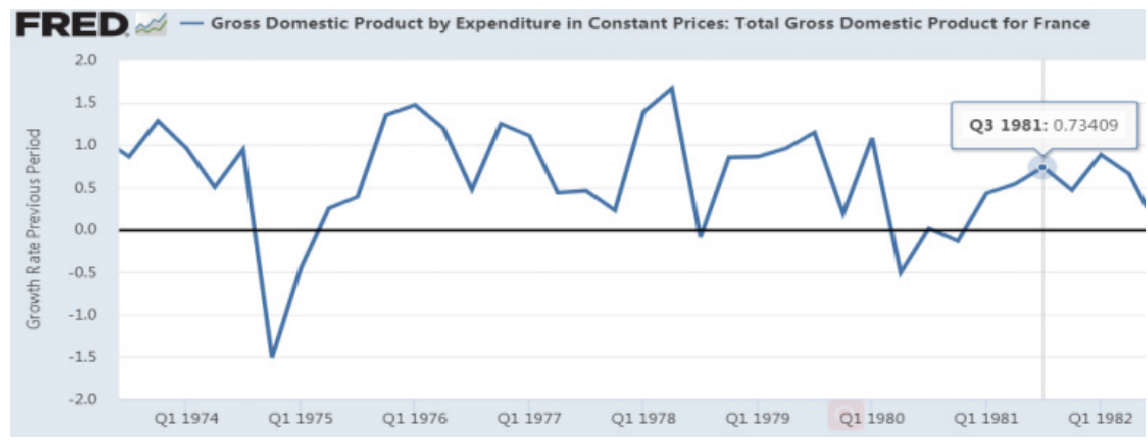

Figure 2. The growth rate also shows the same situation. 


\subsection{High inflation}

As shown in fig. 3, the inflation was really high since 1970s. In 1974 the inflation was about $13 \%$ and in 1980 also around $13 \%$ which were really high compared to the inflation around 3\%-6\% these days in China. Such a high inflation is never easy to control.

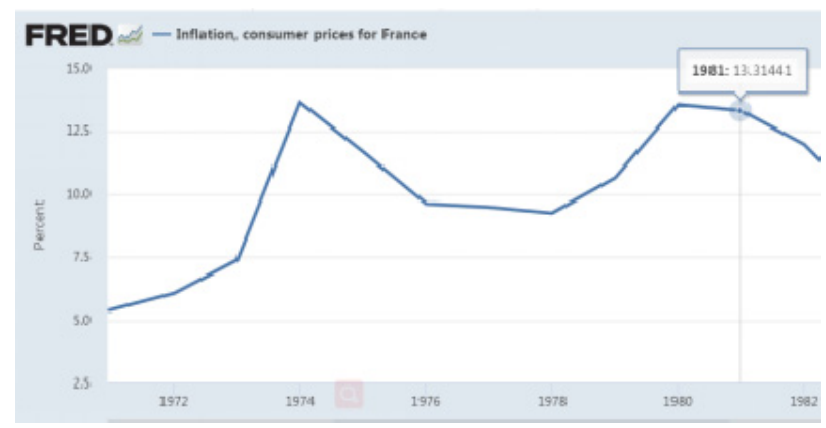

Figure 3. Inflation, consumer prices for France

\subsection{High Unemployment Rate}

The unemployment in France grew rapidly since 1970 and since job is the most important part of people's lives, this rapidly grew unemployment caused many economic problems. Moreover, because the french people focus on their own lives rather than the whole country, the high unemployment became the problem that they mostly concern about. As a result, Mitterrand became the new president with the promise to solve this problem.

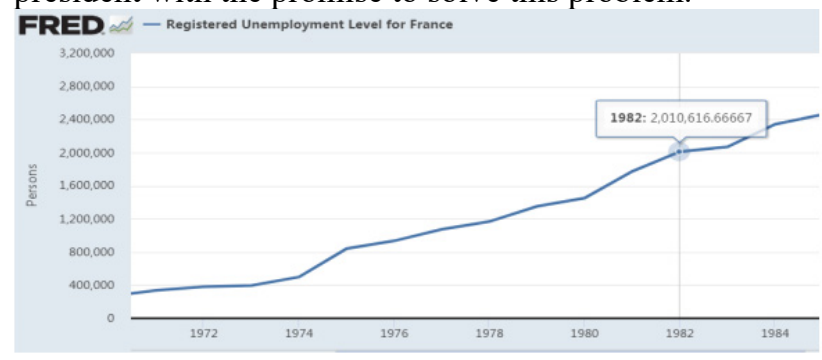

Figure 4. Registered Unemployment Level for France

\subsection{Low Increase in Industry}

Industry was the most important department during that time of French economy. The low increase in industry was a signal for the awful economy. In the graph we can discover a decrease between 1980-1981. It means right before the Mitterrand's govern, the industry has little possibility to recover and would not be able to contribute to the recover of the whole economy.

\subsection{Conclusion}

As a result, People had criticized the economic policy of President Valéry Giscard d'Estaing (1974-1981), the previous president before Mitterrand. And Mitterrand promised to increase employment rate and GDP, which led to his employment-focused policy during 1981 to 1982.

\section{THE ECONOMIC POLICY DURING 1981 TO 1982}

In this article, monetary policy of Mitterrand was the most important part. The author will explain it and evaluate it carefully. However, rather than discussing the monetary policy directly, the whole series of economic policy would be introduced first as to make the whole article clearer.

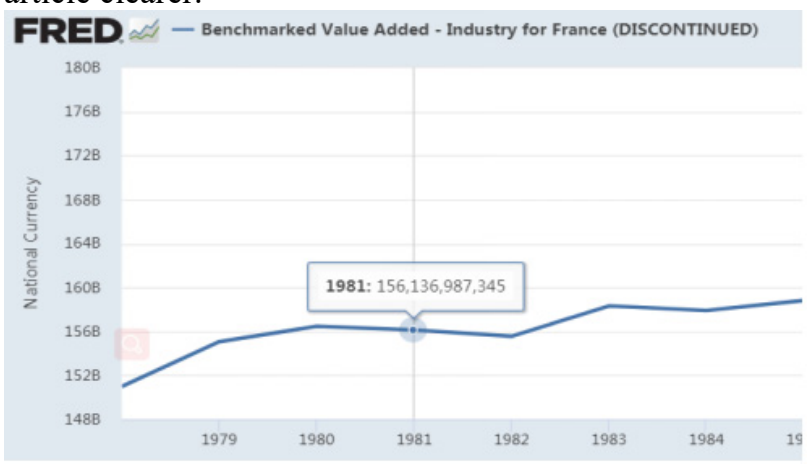

Figure 5. Benchmarked Value Added-Industry for France (DISCOUNTINUED)

\subsection{Economic policy goals}

All these policies are concluded from the papers of [1], [2] and [3].

- Reduce unemployment. Since May 1981, the new regime has announced measures to encourage the growth of private consumption, promote investment in production through tax cuts or expansion of the public sector, and take various measures to increase employment opportunities

- Control inflation. In June 1982, President Mitterrand announced the second phase of French reform to "cut government expenditure" and ensure "control of social budget", as ways to fight against inflation.

- Protect the franc. The French franc has been weak since the day of Mitterrand's inauguration on May 21, when its exchange rate has fallen sharply.This was the prime target of the Mitterrand regime's monetary policy.And we can see that after lots of work that government did, the exchange rate was still a problem.

\subsection{6 economic principles in his plan}

During the election of the French Division in April, Mitterrand officially published his six economic programs. (concluded from article [1] where they find these programs in the newspaper via the Xinhua News Agency in year 1983 and April 8th)

- Nationalization. Maintained the existing economic system while expanded nationalization at the same time. Evidently, nationalization was a policy interested by many European countries at that time. Mitterrand wanted to keep the leading role of state-owned enterprises. 
Meanwhile, the development of the national economy shall be guided by plans by government.

- Tightening credit. Mitterrand wanted to limited money supply as a method to control the high inflation and on the next step to control the price.

- Energy reform. Saving energy and diversifying energy sources, but do not advocate vigorous development of nuclear energy.

- Reforming the taxation system. Eliminating the value-added tax on daily necessities, fostering small and medium-sized enterprises and farmers, and reducing the burden of taxation and social insurance.

- Improving the employment system. Achieve employment equality between men and women, shorten working hours, create a 35 -hour weekly work system, and increase employment opportunities.

- Pursuing social equality. Increase the income of low-wage earners. Limiting the growth of high wages, narrowing the gap between minimum wages and maximum wages. Increase social welfare and subsidies for families with low incomes.

This program focused on employment, but it will encounter a dilemma. If you want to achieve the goals in the first and the third and the goals after the third, government expenditures would increase significantly. As a result, the second goal of controlling credit in this plan would never be realized and vice versa.

When talking about the economic policy that Mitterrand used, France's economic policy can be regarded as a "double loose" policy - an expansionary fiscal policy and an expansionary monetary policy. And these expansionary policy may lead to a serious economic problem since the inflation in this country was already very high.

The Mitterrand regime's economic policy is based on the theories of many economic parties. One was Keynesian elements that stimulate consumption, expand government spending, and the other was supply theories that increase production through tax cuts and structural reforms. Keynesian economic policies dominated the first phase of reform, because the government focused on unemployment rather than inflation unlike the other European countries.

\section{Mitterrand's Monetary Policy}

After the introduction of the economic policy under Mitterrand's leadership during 1981-1982, the monetary policy would be easier to understand. As a part of the economic policy, the goals of the monetary policy must be the same with the whole economic policy or the policies would came into a chaos and dilemma. Then the policy would be a total failure. Though the result of these 1981-1982 policy was a failure, Mitterrand did not give two different orientation for the monetary policy and fiscal policy.

\subsection{Main Goals}

The monetary policy of the Mitterrand regime, like other Western countries, is based on a stable currency. That is, to stabilize the inward and external values of their respective currencies which means to control the inflation and the exchange rate. Finally, to achieve four goals which were reducing unemployment, reducing inflation, promoting economic growth and seeking balance of exchange.

\subsection{Main Methods}

The main methods used by the French Central Bank to implement the Mitterrand's government's monetary policy is to take various measures to maintain the stability of the franc exchange rate and determine the money supply according to the exchange rate system stipulated by the state. These two ways were similar to other west countries at that time. However, France government chose to focused on unemployment rather than the inflation, unlike the other countries.

First method is to protecting France. France has be aiming at a fixed exchange rate system since the Charle s de Gaulle regime until the Mitterrand government in1981. Since the establishment of the European monetary system on March 13, 1979, France and the other seven countries in Western Europe have implemented a fixed exchange rate system within these countries, and implemented a joint floating of major currencies outside the system. As soon as the results of the May 1981 election were announced, the French franc plunged on May 11 and fell to the minimum allowable volatility of the European monetary system. Prime Minister Barr, who was leading the country at the time, still took the lead in protecting the franc in 1981. As we can see in the following graph, the French franc collapsed and the exchange rate of franc per dollar grew rapidly since 1980 . The Mitterrand government used 5 main ways to protect the France.

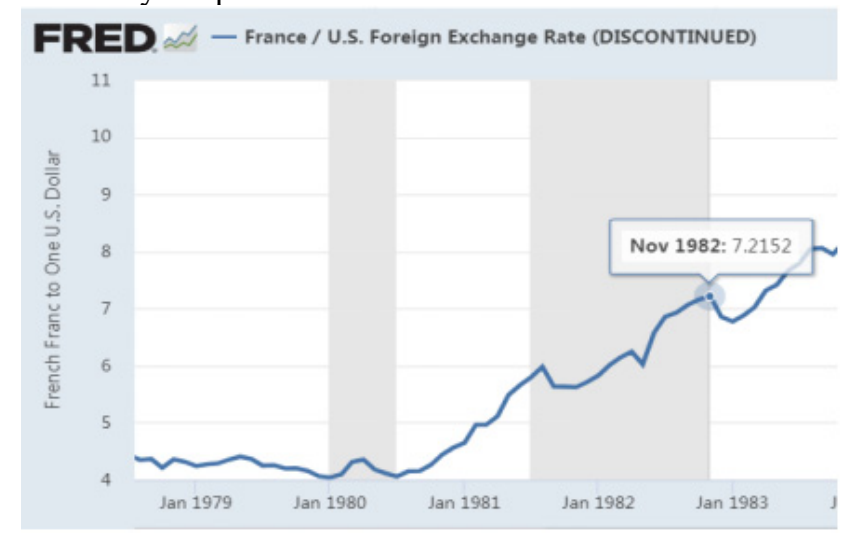

Figure 6. France/U.S. Foreign Exchange Rate (DISCONTINUED)

\subsubsection{Increase the discount rate and interest rate.}

The discount rate increase means an increase in interest rate. And the interest rate increase means an increase in 
the exchange rate. We can see in fig. 7 that the interest rate was very high in 1981 at around $18 \%$.

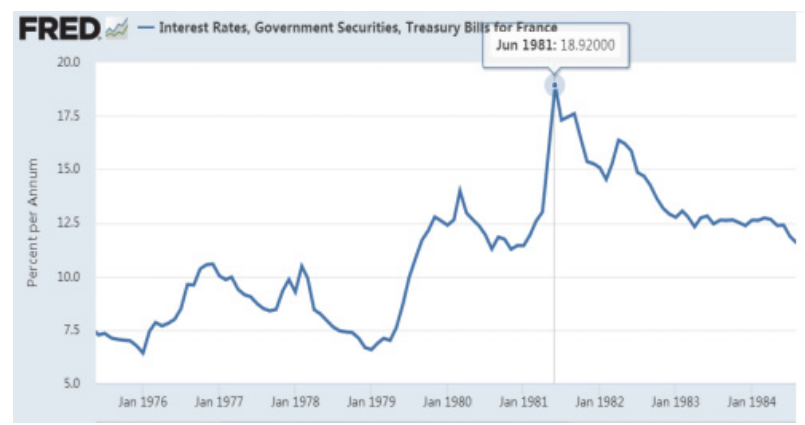

Figure 7. Interest Rates, Government Securities, Treasury Bills for France

\subsubsection{Foreign exchange control by government.}

On the evening of May 21, 1981, the government announced a series of technical measures aimed at defending the exchange rate of the franc. These government policies controls many aspects related with exchange rate, such as foreign investors and exporters as well as tax exemption for export investment. Most importantly, they established a securities foreign exchange system. All these rules were restrictions on the outflow of the franc. Since the franc continuously weak down, the Mitterrand government had announced other policies after to stable the exchange rate.

\subsubsection{Monetary authorities' intervention in the foreign exchange market.}

In addition to strict foreign exchange controls, the French monetary authorities (Bank of France) also purchase foreign exchange in the money market when necessary. This was a very useful way to maintain the franc exchange rate. However, this method need a lot of foreign asset reserve and because of this policy France lost a really huge amount of foreign asset reserve including gold reserve. This can wake the country's ability to control the exchange rate afterwards.

\subsubsection{Adjust the value of the franc in the European monetary system.}

The Mitterrand regime not only wanted a stable exchange rate but also wanted a stable international monetary system.

In order to alleviate the tension between the currency exchange rates of the countries of the Community, and also to alleviate the French intervention and reduce the pressure of stabling the exchange rate and avoid the great loss of excessive foreign exchange reserves, the Community Commission decided to reduce the value of franc among the European community.

For this purpose, Mitterrand made two attempts. One is that in April 1982, Mitterrand wished to establish a monetary support between Europe, France, Japan and Canada to deal with the supremacy of the US dollar Power [6]. Mitterrand also proposed an international conference akin to the Bretton Woods conference of 1944 to discuss reform of the global monetary system [6]. This idea was scuttled by, among others, the Reagan administration. And this was a long plan and cannot rescue the franc in the first two political years of the president Mitterrand.

\subsubsection{Increase the deposit reserve ratio of commercial Banks.}

This policy affected the lending capacity of Banks and made entrepreneurs more difficult to borrow from banks. So, as a result, increase in the deposit reserve ratio of commercial banks would lead to an increases in the interest rate of loans. This policy was actually a contractionary monetary policy and was helpful to restrain inflation at that time though damage the investment.

\subsubsection{Control money supply}

Mitterrand government said that they wanted to control the money supply and did give some policies to control it. However, we can not find a clue that the Mitterrand government had done something to control the money supply.

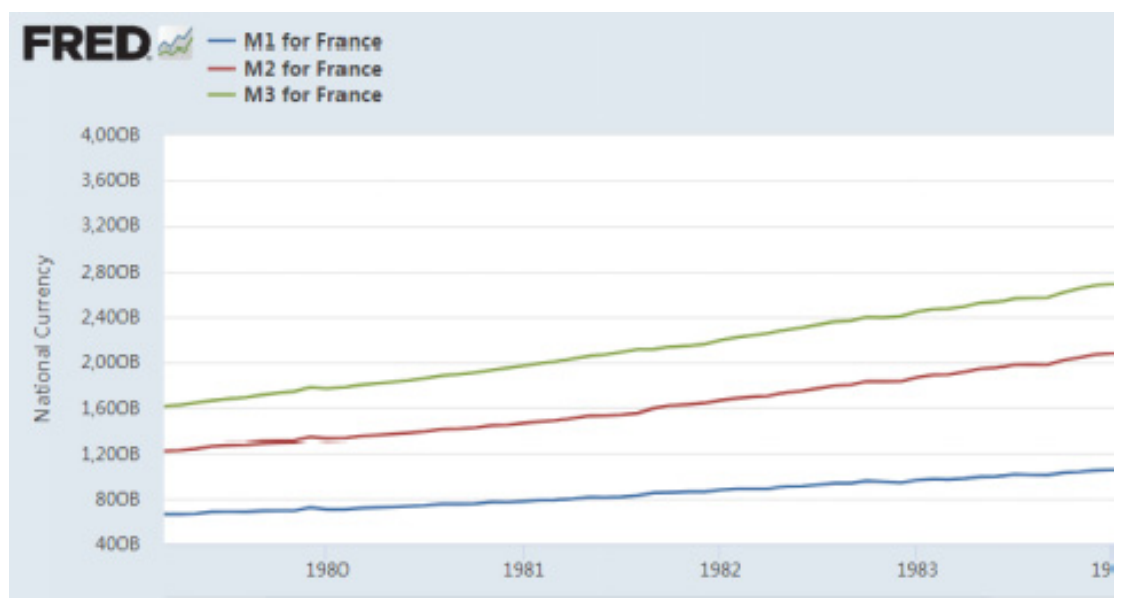

Figure 8. Control money supply. 
Seeing from fig. 8, money supply continues to exceed. A series of expansionary fiscal policies means that monetary policy of this regime had to be expansionary to support it. The growth target for the French money supply in 1981 was $10 \%$ (from December 1980 to December 1981), but the actual growth rate of the money supply was $14 \%$ (from January 1981 to September of the same year), well above the planned growth target.

\section{Evaluation about Mitterrand's Monetary Policy}

\subsection{Advantages}

\subsubsection{Inflation fell in the first four months of 1982.}

As we can see in the fig.3 that the inflation rate decreased a little in some period which was the result of this1981-1982 policy. This was good to a economy and accorded with Mitterrand's goals.

\subsubsection{The growth rate of unemployment has slowed down.}

As was shown in fig. 4, the slope of the line between 1980-1981 are bigger than the slope of the line between 1981-1982, which means the growth rate of unemployment rate has declined during the 1981-1982. This was a good signal for the economy because that means the job losing problem was getting less when the growth rate went down.

\subsubsection{People's productivity and purchasing power has increased.}

Productivity and the purchasing power were very important indicators of a countries macro-economy. The good situation in these two indicator means a good tendency of the economy. And during 1981-1982, though the inflation was still very high, the purchasing power was increased which indicated that people's lives had been better.

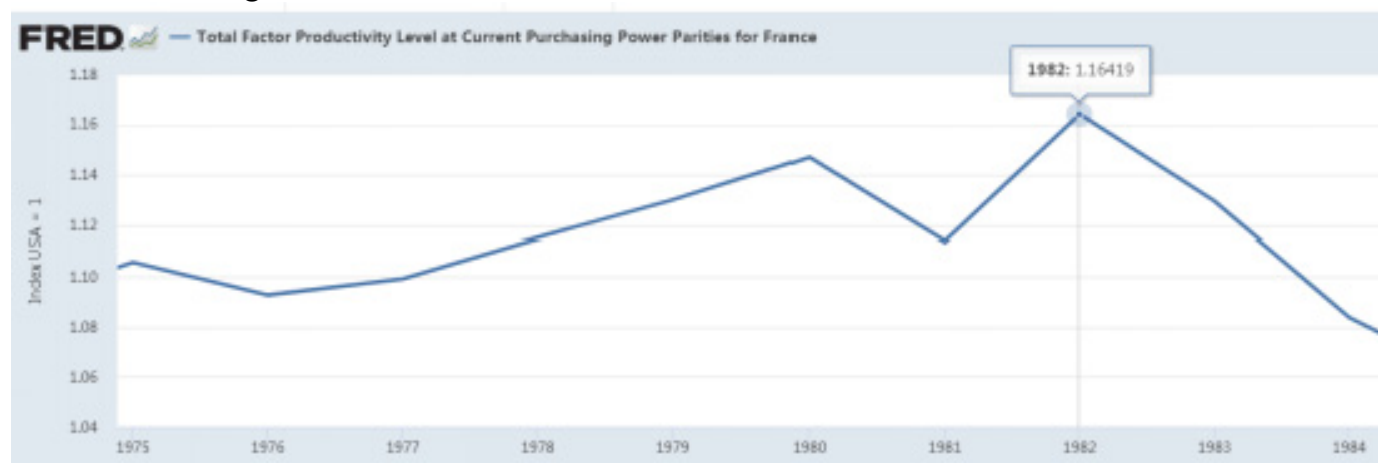

Figure 9. Total Factor Productivity Level at Current Purchasing Power Parities for France.

\subsubsection{GDP grew a little.}

Compared to the decrease in GDP in the 1980, a little growth in GDP was encourage to the whole economy. The expect of these economy could become better according to this fact and the good expect could become the base for the next economic growth.

Besides, these achievement of the France government were all better than other European countries. So that means the Mitterrand government was actually maybe doing a good job. However, as followings would explain, the economy of France was still bad and most goals of the government did not achieved.

\subsection{Disadvantages}

France's economic situation after the implementation of the Mitterrand regime's monetary policy was still bad.

\subsubsection{Slow Economic Growth.}

Although the GDP grew a little and did not decrease anymore, the growth rate was still very low. And this tiny growth in the GDP means France were still at the bottom of a economic cycle, which means the Mitterrand's policies didn't pull the country back to a normal track.

\subsection{2 francs are weakening.}

As shown in fig. 6, francs were still weakening despite some temporary turnaround. So this means the Mitterrand government wasted a lot of foreign exchange reserve and didn't pull the exchange rate back to what they were before the long economic crisis.

This situation may caused by the difference of countries' policy choices [6]. Under the leadership of President Francois Mitterrand, the Socialist government administered a strong fiscal stimulus to the French economy in 1981 and 1982, this choice of reducing unemployment over reducing inflation was diametrically opposed to the choices of most other countries, particularly the United States and the divergence placed downward pressure on the French franc. 


\subsubsection{Gold reserves have been lost in large quantities.}

This was the result of the government buying of the foreign asset to stable the exchange rate. And this situation may lead to a serious result to be forced to use flow exchange rate. So lead the country to a situation that they can not control their exchange rate freely.

\subsubsection{Fiscal deficit continues to expand.}

This was the result of the expansionary policy and may not be solved in a short time. And the expand in the government spending may cause a worse higher inflation. The higher inflation may make the economy even worse.

\subsubsection{The substantial increase of money supply.}

As shown in fig. 8, the money supply continue to increase, and this was a signal for economic expansion which may lead to a worse higher inflation as same as the expansionary fiscal deficit.

\subsubsection{Consumer prices still high.}

We can see in fig. 10 that consumer prices were still very high and so as the inflation rate. So the french people would buy less goods and services and these may drag the economy into a worse situation.

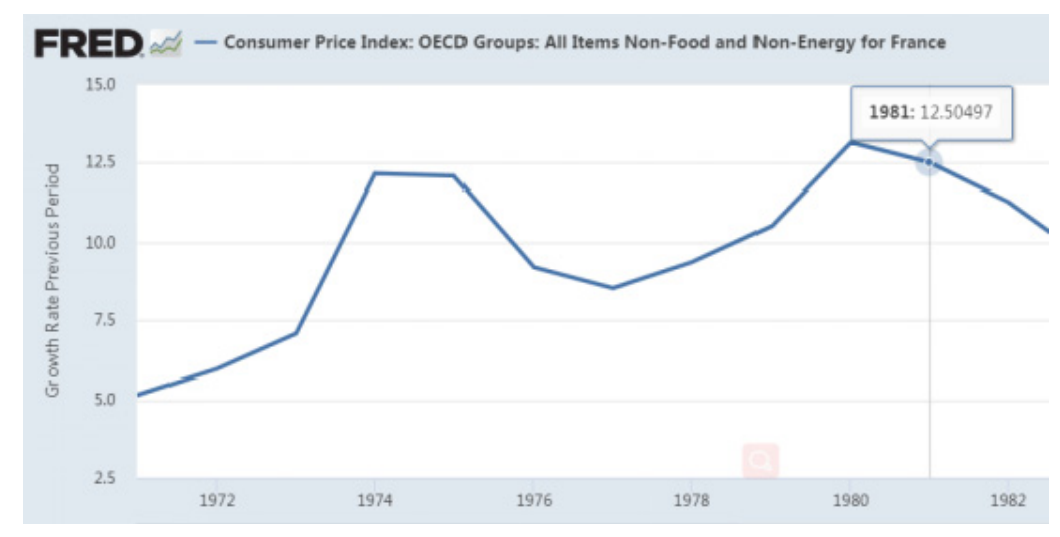

Figure 10. Consumer Price Index

\subsubsection{The number of unemployed people has increased, the problem of unemployment is serious and inflation is serious at the same time.}

Meanwhile in the other countries in Europe, inflation rate was decreased a lot and gradually controlled by the government. However, in France, none of the problems was been solved. So Mitterrand's goals was not achieved and he did not keep his promise to control the unemployment.

\subsubsection{The interest rate in the money market has increased substantially.}

This was a part of the Mitterrand's monetary policy and caused by the government to reached at a so high rate. Such a high interest rate would lead to a great decrease in investment and on the next step to decrease the GDP.

\subsubsection{The trade deficit is growing rapidly.}

We can see from fig. 11 that negative of the net export which is the gap between two lines was increasing rapidly. Remembered that the French foreign asset lost at a huge amount, this problems became more seriously for France. 


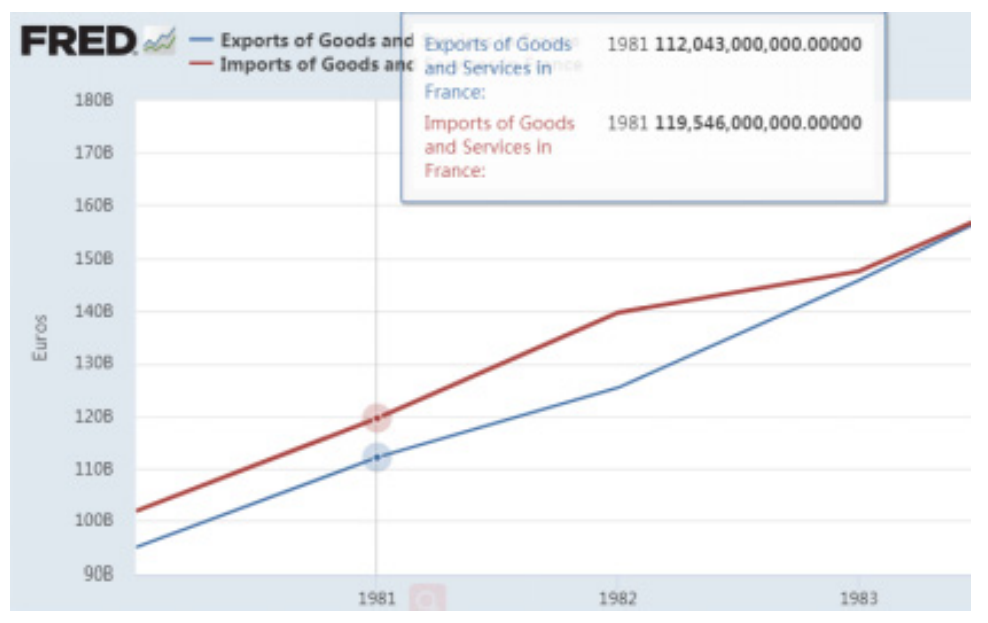

Figure 11. Export and Import of Goods

\subsubsection{Decrease in industrial investment was not good for France at that time since industry was the most important economic department of France.}

\section{CONCLUSION}

According to the previous explanation of the Mitterrand's policy, in the end, the author came into a conclusion that expansionary policy was inappropriate for France in 1981.

The result of Mitterrand's actions was a soaring balance of deficit, accompanying debt of over $\$ 50$ billion (the third largest in the world after Mexico and Brazil), and rampant inflation. The combination of a deficit and high inflation rate signaled the need for economic change [4].

So after this failed attempt in 1981, Mitterrand did change his economic policy a lot in 1983 [4]. Actually, it took the Mitterrand government no more than two years to reverse its expansionary policy stance, only about a year if one notes that by June 1982 fiscal expansion was already being cut back markedly. According to its monetary policy, [8]In March 1983, president Mitterrand arbitrated that France should remain within the European monetary system, at the expense of abandoning the Socialist government's Keynesian attempt to reflate the French economy. And because of his change in 1983, there may be reasons for that the whole series of policies between 1981-1995 may not be a total failure (concluded from [5]).

a) The general deterioration can be dated back to the early 70s. Then the continues decline in the France economy may not be the fault of the Mitterrand's policy.

b) The early and unfortunate attempt at a demand-led expansion was both moderate in size and quickly revive. To see from the time perspective, 1981-1982 were only 2 years, so it was only a short time period during the Mitterrand's leadership.

c) The 1983 anti-inflationary policies have been successful in some ways better than the rest of European countries.

\section{ACKNOWLEDGEMENT}

First and foremost, I would like to show my deepest gratitude to my teachers and professors in my university, who have provided me with valuable guidance in every stage of the writing of this thesis. Further, I would like to thank all my friends and roommates for their encouragement and support. Without all their enlightening instruction and impressive kindness, I could not have completed my thesis.

\section{REFERENCES}

1. Zhou X, Shao Y, (1983) [Try Analyze the Monetary Policy of Mitterrand Regime]. J. Etudes Francaises., 1: 38-46.(in Chinese)

2. Dong P, (1982) [A Preliminary Analysis of Mitterrand's Economic Policies Since He Was Selected]. J. Forum of World Economics \& Politics., 3:50-52.

3. Zhang G, $\mathrm{Hu}$ J, (1981)[Simple Analysis of Mitterrand's New Economic Policy]. J. World Economy, 8:33-36+23.

4. Sachs, J., Wyplosz, C., Buiter, W., Fels, G., deMenil, G. (1986) The Economic Consequences of President Mitterrand. J. Economic Policy., 1: 261-322.

5. Cutler, D., (1984) France: Austerity, French Style. J. Harvard International Review., 6:33-34

6. Randall, C.H., (1998) Systemic Conflict and Regional Monetary Integration: The Case of Europe. J. International Organization., 52:537-573

7. Arnone, M., (1995) French Macroeconomic Policy Under President Mitterrand: an Assessment. J. Rivista Internazionale di Scienze Sociali, 103:743756

8. Cole, A., Drake, H., (1998) Europeanisation of French Politics? J. Economic and Political Weekly., 33:PE99-PE106 